\title{
Fanconi anemia genes are highly expressed in primitive CD34+
} hematopoietic cells

\author{
Michel Aubé1,2, Matthieu Lafrance ${ }^{1,2}$, Isabelle Brodeur ${ }^{1,2}$, Marie- \\ Chantal Delisle ${ }^{1,2}$ and Madeleine Carreau*1,2
}

\begin{abstract}
Address: 1'Unité de génétique humaine et moléculaire, CHUQ-Hôpital St-François d'Assise, 10 rue de l'Espinay, Québec, Qc, Canada G1L 3L5 and ${ }^{2}$ Department of Pediatrics, Laval University, Québec, QC, Canada G1L 3L5

Email: Michel Aubé - aubem@email.com; Matthieu Lafrance - matth_laf@hotmail.com; Isabelle Brodeur - isabrodeur@hotmail.com; MarieChantal Delisle - marie-chantal.delisle@crsfa.ulaval.ca; Madeleine Carreau* - madeleine.carreau@crsfa.ulaval.ca

* Corresponding author
\end{abstract}

Published: 16 June 2003

BMC Blood Disorders 2003, 3:1
Received: 27 February 2003

Accepted: 16 June 2003

This article is available from: http://www.biomedcentral.com/I47|-2326/3/I

(C) 2003 Aubé et al; licensee BioMed Central Ltd. This is an Open Access article: verbatim copying and redistribution of this article are permitted in all media for any purpose, provided this notice is preserved along with the article's original URL.

\begin{abstract}
Background: Fanconi anemia (FA) is a complex recessive genetic disease characterized by progressive bone marrow failure (BM) and a predisposition to cancer. We have previously shown using the Fancc mouse model that the progressive BM failure results from a hematopoietic stem cell defect suggesting that function of the FA genes may reside in primitive hematopoietic stem cells.
\end{abstract}

Methods: Since genes involved in stem cell differentiation and/or maintenance are usually regulated at the transcription level, we used a semiquantitative RT-PCR method to evaluate FA gene transcript levels in purified hematopoietic stem cells.

Results: We show that most FA genes are highly expressed in primitive CD34-positive and negative cells compared to lower levels in more differentiated cells. However, in CD34- stem cells the Fancc gene was found to be expressed at low levels while Fancg was undetectable in this population. Furthermore, Fancg expression is significantly decreased in Fancc -/- stem cells as compared to wild-type cells while the cancer susceptibility genes Brcal and Fancd//Brac2 are upregulated in Fancc-/- hematopoietic cells.

Conclusions: These results suggest that FA genes are regulated at the mRNA level, that increased Fancc expression in $\mathrm{LTS}-\mathrm{CD} 34^{+}$cells correlates with a role at the $\mathrm{CD} 34^{+}$differentiation stage and that lack of Fancc affects the expression of other FA gene, more specifically Fancg and Fancd I/Brca2, through an unknown mechanism.

\section{Background}

Fanconi anemia (FA) is a genetic autosomal recessive disease characterised by bone marrow (BM) failure associated with cancer susceptibility and congenital defects [1]. Somatic cell fusion studies of FA cells have revealed eight complementation groups suggesting the existence of at least eight genes implicated in the disease [2]. Six FA genes have been cloned, FANCA, FANCC, FANCD2, FANCE,
FANCF and FANCG and recently the Breast cancer susceptibility gene, BRCA2, has been assigned to complementation group D1 and possibly to group B although this requires further confirmation [3-10]. Knockout mouse models from complementation group A (Fanca -/-), C (Fancc -/-) and G (Fancg -/-) have been generated in order to study the molecular basis of this disease [11-14]. Bone marrow (BM) failure similar to that observed in FA 
patients was shown in Fancc -/- mice after treatment with a DNA damaging agent, mitomycin $\mathrm{C}$, showing progressive pancytopenia and reduced BM cellularity [15]. Also, hematopoietic stem cells from Fancc -/- mice were shown to have a reduced long-term reconstitution ability in recipient mice concomitant with a reduced number of primitive (Lin-) Thy $1.2^{\text {low }_{\mathrm{C}}-k i{ }^{+} \mathrm{Sca}-{ }^{+}{ }^{+} \mathrm{CD} 34^{+} \text {hematopoi- }}$ etic cells $[16,17]$. These results suggest that FA genes may be involved at specific stages of stem cell growth and/or differentiation. Since genes involved in stem cell differentiation are highly regulated at the RNA level [18-22], we evaluated FA genes expression pattern in murine hematopoietic cell populations more specifically in lineage-negative (Lin-) Thy1.2-Sca- $1+$ CD34 ${ }^{+}$and Thy1.2-Sca- $1+$ CD34stem cells. Our results show that in wild-type BM, FA genes are highly expressed in the Lin-Thy1.2-Sca-1+CD34+ stem cell population and that Fanc gene expression is altered in Fancc -/- hematopoietic cells.

\section{Methods}

\section{Hematopoietic cell purification}

Bone marrow (BM) cells were obtained from 4 to 6 month old Fancc -/- and Fancc +/+ mice (C57BL/6J, 11 th generation of backcrosses) as previously described [17]. Bone marrow were collected from femurs, tibias and humeri, resuspended in PBS supplemented with $2 \%$ fetal bovine serum (FBS, Life Technologies, Burlington, ON, Canada) and depleted of red blood cells in ammonium chloride solution (StemCell Technologies Inc., Vancouver, BC, Canada) for $10 \mathrm{~min}$ at $4{ }^{\circ} \mathrm{C}$. Total BM cells were either used for RT-PCR analysis or further divided into subpopulations as follows. Total BM cells were depleted of lineage (CD5, CD45R, CD11b, myeloid differentiation antigen Gr-1, TER 119) and Thy1.2 positive cells using StemSep negative cell selection procedure as described by the manufacturer (StemCell Technologies Inc., Vancouver, BC, Canada). The lineage and Thy1.2 depleted (Lin-) cell population obtained was either used for gene expression analysis or further sorted into Sca- $1^{+}$CD $34^{+}$(LTSCD34+) or Sca- $1^{+}$CD34- (LTS-CD34-) populations as previously described [17]. Briefly, Lin-Thy1.2- cells were labeled with fluorochrome conjugated rat anti-mouse antibodies directed against CD34 and Sca-1 antigens (FITC-CD34 and PE-Sca-1, Ly-6A/E; PharMingen, Mississauga, ON, Canada). Rat IgG2a monoclonal antibodies conjugated to FITC or PE were used as isotype standards. Cells were labeled $30 \mathrm{~min}$ at $4^{\circ} \mathrm{C}$, washed and resuspended in PBS supplemented with 2\% FBS. Cells were sorted on an Epics Coulter cell sorter (BeckmanCoulter Canada, Mississauga, ON, Canada). Cells were defined by forward (FSC) and side (SSC) scatter and gated for Sca- $1^{+}$ and CD34+ (LTS-CD34+) or CD34- (LTS-CD34-) populations (Figure 1A). Re-analysis of sorted Sca- $1^{+} \mathrm{CD} 34^{+}$and Sca- $1{ }^{+}$CD 34 - cells showed a purity of 85 to $95 \%$ in each fraction (Figure 1B). Purity of each cell fraction was also
A

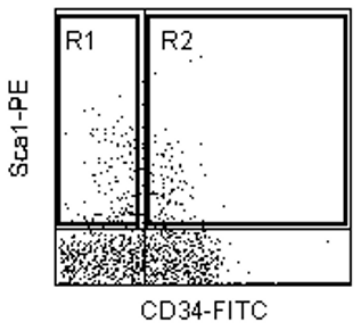

B
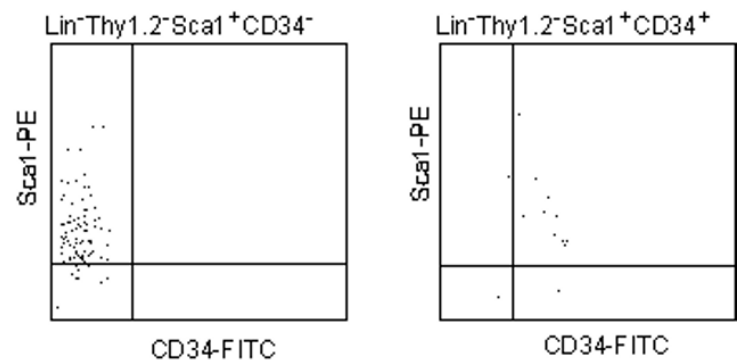

C

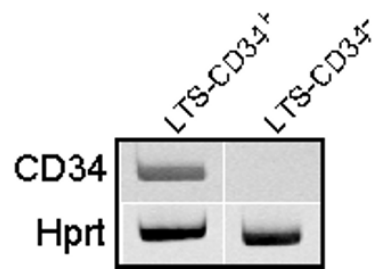

Figure I

Sorting regions used for LTS-CD34 ${ }^{+}$and LTS-CD34cell purification. (A) Lineage and Thyl.2 positive cells were removed from murine BM cell preparation as described in materials and methods. Lin-Thyl.2- cells were sorted on the basis of CD34 and Sca-I expression using RI and R2 sorting windows. (B) Reanalysis of sorted Lin-Thyl.2-Sca-I+CD34and Lin-Thyl.2-Scal I ${ }^{+}$CD $34^{+}$cells. (C) Representative gel electrophoresis of RT-PCR products in sorted Lin-Thyl.2Scal ${ }^{+}$CD34- and Lin-Thyl.2-Scal ${ }^{+}$CD $34{ }^{+}$cells from wild-type mice using either murine CD34 or Hprt primers.

evaluated by RT-PCR as described below using specific murine CD34 primers (Table 1). No CD34 mRNA expression was detected in sorted LTS-CD34- fraction (Figure 1C). Animal experiments were approved by the Animal Care Committee of Laval University, QC, Canada.

\section{RNA extraction and RT-PCR analysis}

One to $5 \times 10^{6}$ of total hematopoietic or Lin-Thy1.2- cells were used for total RNA purification and RT-PCR analysis. Total RNA was extracted using TRIZOL reagent (Life technologies) as described by the manufacturer and 
Table I: Oligonucleotides primers used for PCR analysis

\begin{tabular}{|c|c|c|c|c|c|}
\hline \multirow{2}{*}{$\begin{array}{l}\text { Genes } \\
\text { Fanca }\end{array}$} & \multicolumn{2}{|c|}{ Primer sequences } & \multirow{2}{*}{$\begin{array}{l}\text { Position on cDNA } \\
2955\end{array}$} & \multirow{2}{*}{$\begin{array}{l}\text { Size of PCR fragment } \\
457\end{array}$} & \multirow{2}{*}{$\begin{array}{l}\text { Accession number } \\
\text { XMI } 25090\end{array}$} \\
\hline & S & 5'-tccttgtcagcgagatcatg & & & \\
\hline & $A$ & 5'-cctgaagaagtggatggtaat & 3412 & & \\
\hline \multirow[t]{2}{*}{ Fance } & S & 5'-cttacggtgctccatgtcttg & 1337 & 653 & NM007985 \\
\hline & $A$ & 5'-ctgagcagcatcaggagacgg & 1990 & & \\
\hline \multirow[t]{2}{*}{ Fancd I/Brca2 } & S & 5'-agccccatgcagcctccacttg & 9394 & 259 & NM009765 \\
\hline & $A$ & 5'-cggggacggtaagggcagcc & 9653 & & \\
\hline \multirow[t]{2}{*}{ Fancd2 } & S & 5'-gccgggctttgagatgatc & 913 & 418 & AKO19136 \\
\hline & $A$ & 5'-ccgtgcagggaccagaaca & 1331 & & \\
\hline \multirow[t]{2}{*}{ Fance } & $S$ & $5 '-$ ggccctcgtctccttctgtg & 1103 & 246 & AKOI3325 \\
\hline & $A$ & 5 -gctctgctgctctgtgatctg & 1349 & & \\
\hline \multirow[t]{2}{*}{ Fancf } & S & 5 -cacgaggtccctacacagatggaggacatg & ND & 228 & *H.Joenje \\
\hline & $A$ & 5'-agcctgggaactgagaatctactctagcac & & & \\
\hline \multirow[t]{2}{*}{ Fancg } & S & 5 -tccccacccacctcctctctag & 1176 & 317 & AY0497I5 \\
\hline & $A$ & 5'-caggcagggtccgaaagagcag & 1493 & & \\
\hline \multirow[t]{2}{*}{ Brcal } & $S$ & 5'-cagcgggcgaccatgaagtataa & 4260 & 304 & $X M / 26697$ \\
\hline & $A$ & 5'-ggccttcccatccctgactcgt & 4564 & & \\
\hline \multirow[t]{2}{*}{ Hprt } & $S$ & 5'-agtcccagcgtcgtgattag & 100 & 269 & NM0I3556 \\
\hline & $A$ & 5 '-aggaatggatctatcactat & 369 & & \\
\hline \multirow[t]{2}{*}{ CD34 } & $S$ & 5'-atgcaggtccacagggacacg & 51 & 220 & BC006607 \\
\hline & $A$ & 5 -ctgtcctgatagatcaagtag & 271 & & \\
\hline
\end{tabular}

S, sense; A, anti-sense; ND, unkown *Primer sequences provided by Dr. $\mathrm{H}$ Joenje, Free University Amsterdam

resuspended in diethylpyrocarbonate (DEPC)-treated water containing ribonuclease inhibitor Superase in $^{\mathrm{TM}}(1$ $\mathrm{U} / \mu \mathrm{l}$, Ambion, Austin, TX, USA). For total BM and Lin Thy $1.2^{-}$cells, RNA concentration was quantified by spectrophotometry at $260 \mathrm{~nm}$ and $400 \mathrm{ng}$ of total RNA was used for RT-PCR analysis. For LTS-CD34+ and LTS-CD34stem cell populations, the RNA extraction protocol was modified to improve yield from small cell numbers ranging from 5000 to 35000 cells. Briefly, total RNA was extracted using TRIZOL reagent and precipitated with glycogen as carrier. Each RNA preparation from LTS-CD34+ and LTS-CD34- stem cells was used directly in RT-PCR reactions. The reverse transcription reaction was done with oligo (dT) primers using the SuperScript ${ }^{\mathrm{TM}}$ II protocol as described by the manufacturer (Life technologies). For PCR amplification, 10 to $20 \%$ of cDNAs from each cell preparation was directly added to a standard PCR amplification mixture. Sense and anti-sense primer sequences and the corresponding CDNA PCR product sizes are shown in Table 1. First, we determined optimal PCR conditions for linear amplification of gene transcripts and to avoid saturation conditions. Linear amplification of the hypoxanthine guanine phosphoribosyl transferase gene (Hprt) were obtained with cDNA obtained from 10 to 50 ng of total RNA or with RNA extracted from 6000 to 60 000 hematopoietic cells (data not shown). Thirty cycles for BM or Lin- cell RNA extract or 35 cycles for LTS-CD34+ or LTS-CD34- cell RNA extract was carried out and found to be in the linear PCR reaction range. PCR products were separated on $8 \%$ polyacrylamide gel and visualized by ethidium bromide staining. Volumes of 5 or $10 \mathrm{ul}$ of PCR products were deposited on gels according to the expression level of each gene. Signal intensities were analyzed using the BioRad Quantity one ${ }^{\mathrm{TM}}$ software. The relative expression level for each target gene was quantified by calculating the ratio of the target gene intensity signal to the Hprt intensity signal obtained from the same cDNA preparation and visualized on the same gel. Specificity of all primers was further confirmed by direct nucleotide sequencing analysis of PCR products. Each RNA extraction products were tested and found free of DNA contamination using PCR amplification on samples without RT reactions. Statistical analysis were performed using the Student $t$-test.

\section{Results}

FA genes are highly expressed in murine wild-type primitive hematopoietic cells

Several studies have surveyed changes in the expression profiles of many genes associated with hematopoietic cell growth and differentiation such as transcription factors, cytokine receptors and ligands, cell cycle related genes and integrins [18-22]. Since the hematopoietic defect in Fanconi anemia is thought to reside in the stem cell compartment [17], we sought to determine the expression profile of FA genes in murine hematopoietic stem and progenitor cells. We evaluated the mRNA expression levels of FA genes from complementation group A, C, D1/Brca2, D2, $\mathrm{E}, \mathrm{F}$ and $\mathrm{G}$ in sorted hematopoietic stem cell fractions using a semiquantitative RT-PCR procedure. The relative 
Table 2: FA gene expression ratios in Fancc -/- hematopoietic cell population as compared to Fancc+/+ cells

\begin{tabular}{lrrrr}
\hline & BM & Lin-Thyl.2- & LTS-CD34+ & LTS-CD34- \\
\hline Fanca & $5.1 \uparrow$ & $7.0 \uparrow$ & 0.45 & 1.3 \\
FancdI/Brca2 & $3.3 \uparrow$ & $2.6 \uparrow$ & 2.9 & 0.58 \\
Fancd2 & $4.3 \uparrow$ & $0.18 \downarrow$ & 0.76 & 1.5 \\
Fance & $0.75 \downarrow$ & 0.95 & 1.5 & 0.37 \\
Fancf & 1.1 & 1.1 & 0.46 & 0.79 \\
Fancg & 1.8 & 1.3 & $0.06 \downarrow$ & 1.7 \\
Brcal & $7.0 \uparrow$ & $2.5 \uparrow$ & 1.7 & 1.7
\end{tabular}

$\uparrow$ Significant increased expression levels in Fancc -/- cells; $\downarrow$ Significant decreased expression levels in Fancc -/- cells -: Gene expression not detected neither in Fancc +/+ nor Fancc -/- cells

expression of each FA gene was based on the housekeeping gene Hprt transcription level (equivalent to 1) in each sample tested allowing the comparison of Fanc gene expression levels between murine $\mathrm{BM}$, lineage and Thy1.2-depleted, LTS-CD34+ and LTS-CD34- hematopoietic cells. We found that Fanca, Fancc, Fancd2 and Fancg were highly expressed in LTS-CD34+ cells (Fanc/Hprt ratios ranging from 0.45 to 0.75) whereas Fancd1/Brca2, Fance, Fancf and the FA-associated cancer susceptibility gene Brca1 were expressed at low levels in these cells with ratios ranging from 0.09 to 0.30 (Figure 2 and 4). Expression of all Fanc genes tested was dramatically low in both BM and Lin-Thy1.2- cells with relative expression ranging from 0.029 to 0.36 . Both Fance and Fancf were expressed at low levels in all BM cell populations tested with relative expression of 0.07 to 0.27 and 0.14 to 0.30 respectively.

Adult murine long-term repopulating stem cells are thought to reside in the CD34-cell compartment while $\mathrm{CD} 34^{+}$cells have short-term reconstitution potential [2325]. We measured Fanc gene mRNA expression in the LTSCD34- cell fraction. Our results show that Fanca is highly expressed in LTS-CD34- cells (ratio of $0.875 \pm 0.045$ ) whereas other Fanc genes showed low mRNA expression levels (ratio ranging from 0.085 to 0.33 ). In addition, we were unable to detect Fancg expression in LTS-CD34- stem cells (4 independent reactions). Our results suggest that most Fanc genes, and more dramatically Fancc and Fancg are upregulated in murine LTS-CD $34^{+}$cells correlating with a specific role at this hematopoietic cell differentiation stage.

Fanc genes are disregulated in Fancc-/- hematopoietic cells We investigated the expression levels of Fanc genes in Fancc-/- hematopoietic cells in order to verify if absence of one FA gene, notably the murine Fancc, affects the expression profile of other Fanc genes. Our results show that Fanca, and Fancd 2 are significantly upregulated in Fancc /- total BM cells as compared to Fancc+/+ cells while Fance, Fancf and Fancg expression levels are either down regulated or unchanged (Figure 3). Similarly, Fanca showed a 7 fold significant increase in mRNA expression in Fancc-/- progenitors (Lin-Thy1.2-) compared to Fancc+/ + cells (Table 2). Surprisignly, Fancc-/- progenitor cells showed lower Fancd2 mRNA levels with an expression ratio of 0.18 compared to Fancc $+/+$ cells while Fance, Fancf and Fancg expression levels were similar between Fancc -/- and Fancc+/+ Lin-Thy1.2- cells.

We also evaluated Fanc mRNA expression in both CD34+ and CD34- stem cells. We show that Fancg expression is significantly decreased in Fancc-/- LTS-CD34+ cells as compared to Fancc+/+ cells (ratio of 0.06). Again, Fancg expression could not be detected in Fancc-/- LTS-CD34cells as in Fancc+/+ cells. Other Fanc genes, Fanca, Fancd2, Fance or Fancf, did not show any significant changes in mRNA expression in Fancc-/- LTS-CD34+ and Fancc-/- LTSCD34- cells as compared to Fancc+/+ cells. These results suggest that absence of Fancc influences mRNA expression levels of other Fanc genes in progenitors and total BM cells.

The breast cancer susceptibility genes, Brcal and Brca2I Fancd I are upregulated in Fancc-l- hematopoietic cells We evaluated mRNA expression levels of the newly identified FA gene Brca2/Fancd1, and the FA-associated gene, Brca1, in Fancc+/+ and Fancc-/- hematopoietic cells. We found that both Brca2/Fancd1 and Brca1 genes were expressed at low levels in all Fancc+/+ hematopoietic cell populations tested (ratios ranging from 0.29 to 0.36 and 0.09 to 0.24 , respectively; Figure 4 ). We also evaluated mRNA levels in Fancc-/- hematopoeitic cells and found that both Brca2/Fancd1 and Brca1 are upregulated in Fancc-/- total BM, progenitors and CD $34^{+}$cells. Of all the FA genes tested, Fancd1/Brca2 and the FA associated gene Brcal seemed to be the most affected from absence of Fancc with 5 to 7 fold increase in gene expression levels in Fancc-/- differentiated BM cells and progenitors (LinThy1.2-), respectively (Table 2). 
A
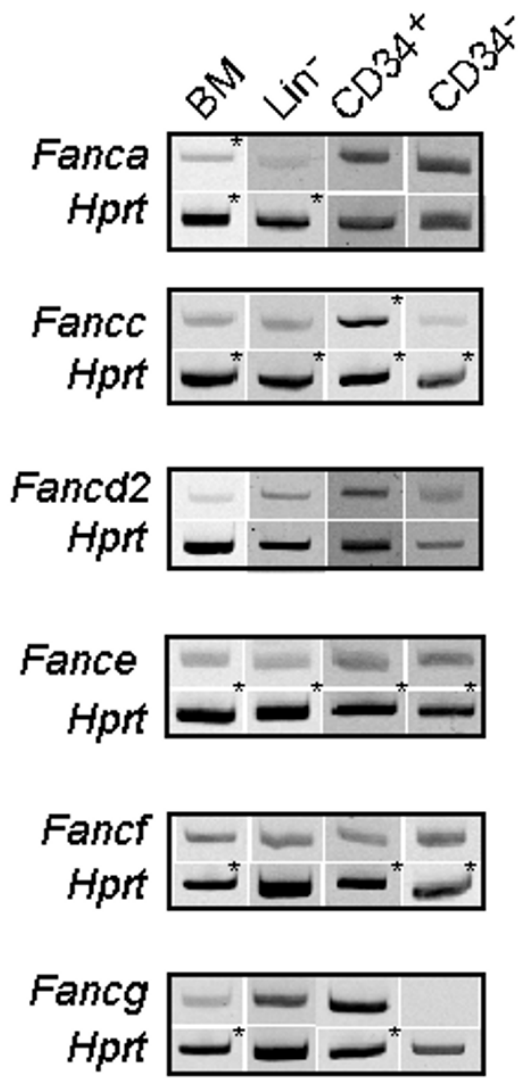
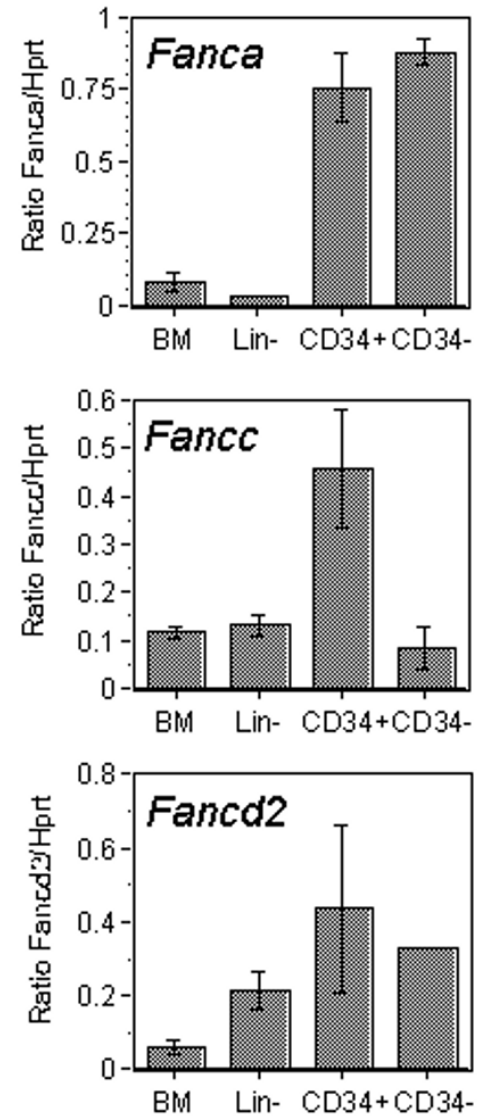
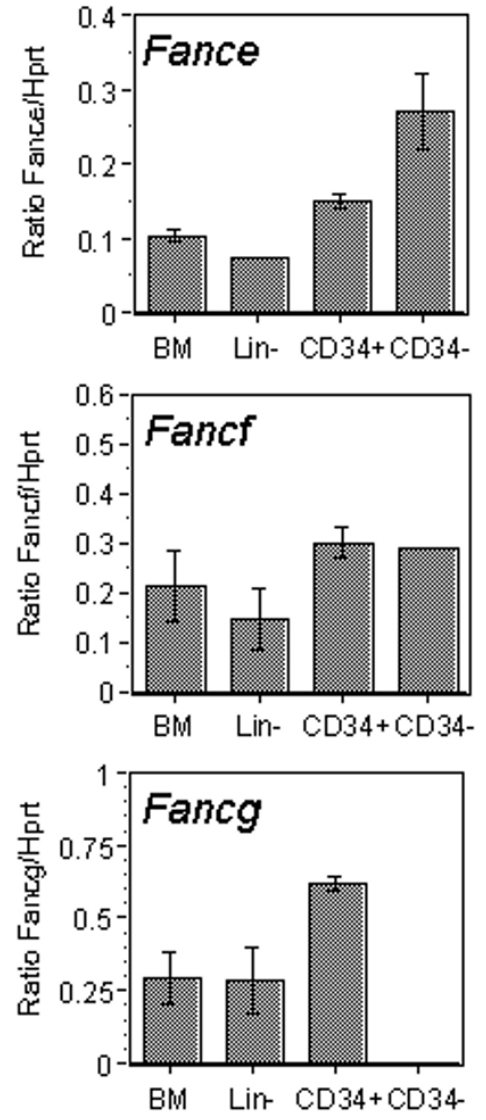

Figure 2

Fanc gene expression profiles in murine hematopoietic cells. (A) Representative gel electrophoresis of $10 \mathrm{ul}(*$ represents $5 \mathrm{ul}$ ) of RT-PCR products from wild-type BM (BM), lineage and Thyl.2-depleated (Lin-) and sorted LTS-CD34+ (CD34+) and LTS-CD34- (CD34-) cells using specific Fanc and Hprt primers. (B) Mean relative expression of Fanc genes in wild-type hematopoietic cell populations from 2 to 10 separate determinations with the exception of Fancf in CD34- cells where values represent one determination. Fancg expression in CD34- cells was undetectable $(n=4)$.

It is difficult to know if the observed increase in Brca gene expression in Fancc-/- hematopoietic cells is also reflected at the protein level. Since there are no commercially available antibodies directed against murine Brca proteins, we used anti-human BRCA1 and BRCA2 antibodies in Western blot and immunoprecipitation techniques and could not detect murine Brca1 and Brca2 proteins (data not shown). Thus, we could not evaluate protein expression levels in Fancc-/- BM cells to determine if the observed mRNA expression profiles correlated with protein expression levels.

Nevertheless, these results suggest that absence of Fancc affects the regulation of other Fanc gene expression more dramatically, Brca2/Fancd1 and Brca1, through an unknown mechanism.

\section{Discussion}

Gene expression profiling and transcription regulation of different genes can be surveyed using several techniques such as Northern blots, differential display or microarray technology. Some may provide information on numerous genes simultaneously such as microarrays, but these tend to generate large and complex data. We chose a simple direct semiquantitative RT-PCR procedure to characterize specific gene expression levels in sorted hematopoietic stem and progenitor cell fractions. Since primitive hematopoietic stem cells are only obtainable in very limited amounts, PCR based methods are more sensitive and 
A
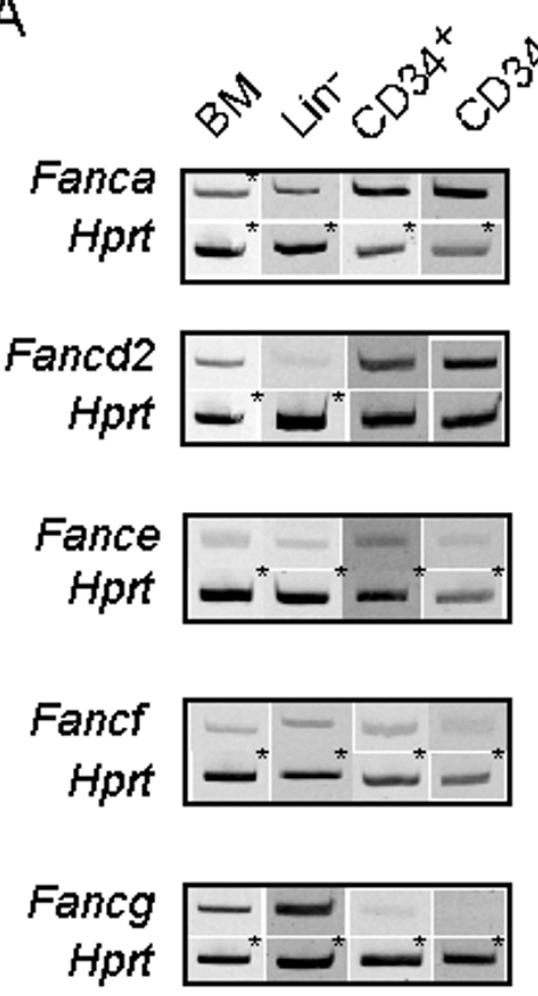
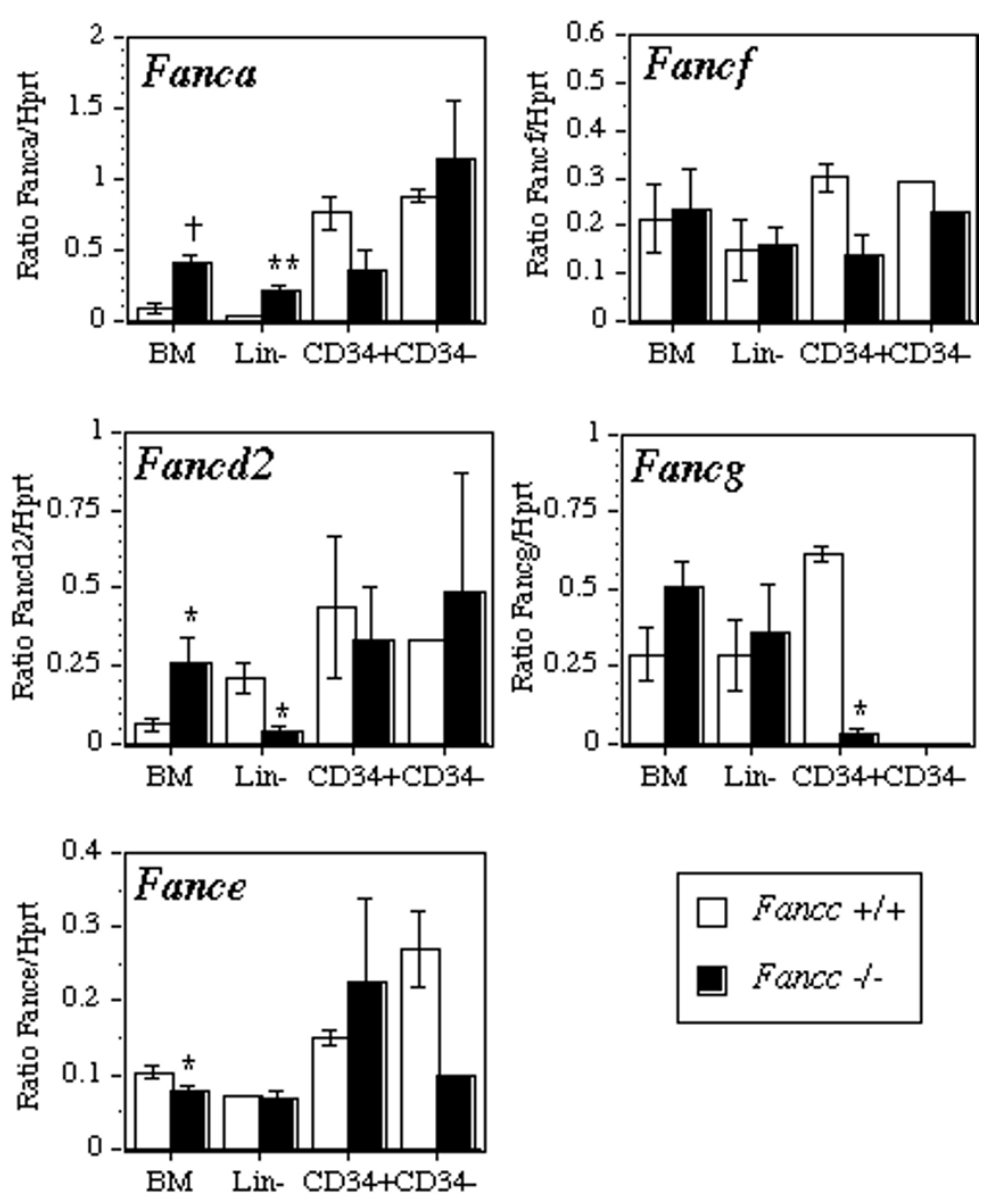

Fancc $+1+$

Fance $1-$

Figure 3

Comparative analysis of Fanc gene expression in hematopoietic cells from Fancc-/- mice. (A) Representative gel electrophoresis of $10 \mathrm{ul} \mathrm{(*} \mathrm{represents} 5 \mathrm{ul}$ ) of RT-PCR products from Fancc -/- BM cells, BM; lineage and Thyl.2-depleated, Lin; sorted LTS-CD34+, CD34+; and LTS-CD34-, CD34- cells using specific Fanc and Hprt primers. (B) Quantitative comparison of the expression levels of Fanc genes in hematopoietic cell populations from Fancc+/+ and Fancc-/- mice. Bars represent the mean value from 2 to 10 separate determinations with the exception of Fance and Fancf in CD34- cells where values represent one determination. Fancg expression in CD34- cells was undetectable in both Fancc $+/+(n=4)$ and Fancc-/- cells $(n=4)$. Fancc $+/+$ expression ratios are identical to those in Figure 2. Significant differences between Fancc -/- and Fancc $+/+$ cells where $* p<$ 0.05 , ** $p<0.005$ and $\dagger p<0.001$.

allow the detection of low abundance transcripts in small cell populations as compared to Northern blot analysis. In addition, we used single-round PCR amplifications followed by direct detection on polyacrylamid gels to keep relative abundance relationship between transcripts and to reduce variability between samples. The reverse transcription was performed using oligo (dT) primers and target gene expression ratios were based on the housekeeping gene, Hprt, transcription level (equivalent to 1.0) in the same sample, thus, allowing the comparison between different genes, between cell populations and between wild-type and Fancc-/- cells.
In the current study, we tested the hypothesis that Fanc genes display a pattern of expression reminiscent of a role in hematopoietic stem cell differentiation and/or maintenance. Based on phenotypic analysis of Fancc -/- mouse bone marrow, targeted deletion of Fancc alleles was shown to affect the number of primitive $\mathrm{CD} 34^{+}$cells suggestive of a role at the $\mathrm{CD} 34^{+}$stem cell differentiation stage [17]. We found that expression of most FA genes, notably, Fanca, Fancc, Fancd2 and Fancg, are highly expressed in $\mathrm{CD}_{34}{ }^{+}$stem cells as compared to more differentiated cell populations whereas Fance and Fancf are expressed at similar levels in all hematopoietic cell popu- 
A
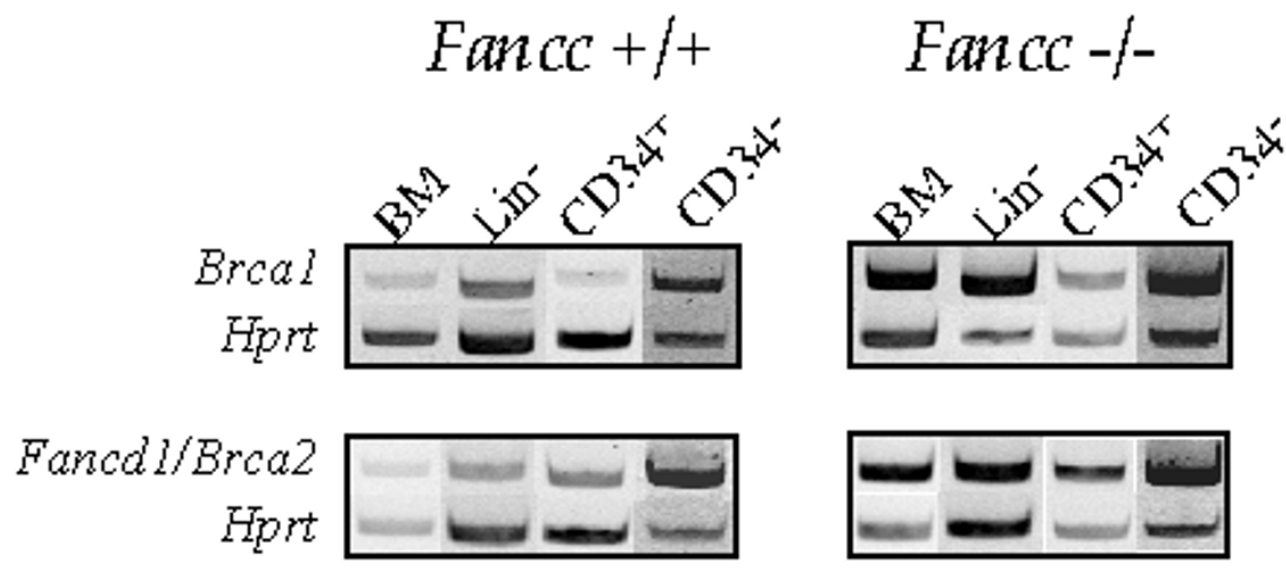

B
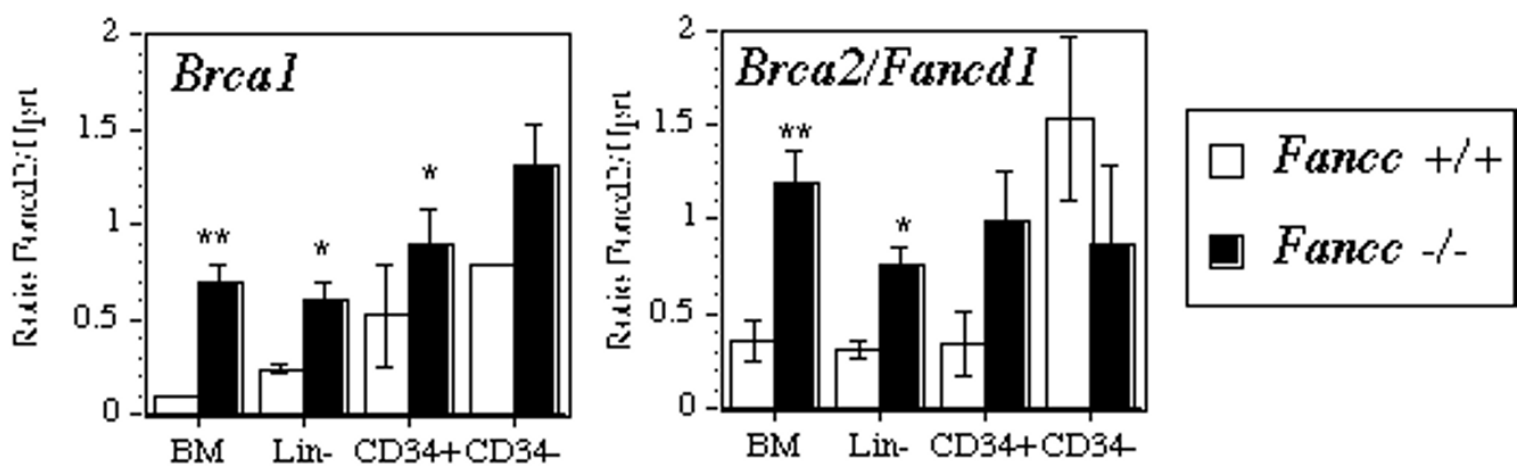

Figure 4

Comparative analysis of Brcal and Brca2/Fancd I gene expression in hematopoietic cells from Fancc-/- mice. (A) Representative gel electrophoresis of $10 \mathrm{ul}$ and $5 \mathrm{ul}$ of RT-PCR products using specific Brcal or Brca2/Fancd I and Hprt primers, respectively, from Fancc -/- BM cells, BM; lineage and Thyl.2-depleated, Lin-; sorted LTS-CD34+, CD34+; and LTS-CD34-,

CD34- cells. (B) Quantitative comparison of the expression levels of Brcal and Brca2/Fancd I genes in hematopoietic cell populations from Fancc+/+ and Fancc-/- mice. Bars represent the mean value from 4 to 10 separate determinations. Absence of SEM bars represents values to low to appear. Significant differences between Fancc -/- and Fancc +/+ cells where *p $<0.05$ and $* * P$ $<0.005$.

lations. We showed that Fanca was highly expressed in both long-term CD34- and short-term CD34+ stem cells whereas Fancc and Fancg appear to be downregulated in LTS-CD34- stem cells and upregulated in CD34+ cells consistent with a role of Fancc at the CD34- to CD34+ differentiation stage[17]. The fact that Fancg is undetectable in CD34- stem cells and highly expressed in CD34+cells suggest that this gene may also function at the CD34+ stage. Taken together, these results suggest that Fanc genes are differently regulated in hematopoietic stem cells and suggest that each FA proteins may act separately from the FA complex during hematopoiesis similarly to what has been suggested for MMC sensitivity and cytokine signaling [2629].

Our results showing increased Fanca and Fancc expression in primitive hematopoietic stem cells and reduced levels in differentiated BM cells are consistent with previous studies showing Fanca and Fancc expression in cells of mesenchymal origin that give rise to hematopoietic tissues during mouse development [30]. In addition, studies showing Fancc expression in areas undergoing osteogenesis, in regions containing dividing and/or differentiating cells, in progenitor/precursor cell popula- 
tions and in primordial germ cell development are also consistent with our results showing elevated Fancc expression in primitive hematopoietic cells [20,32-34].

Mouse models for Fanca, Fancc and Fancg have been generated [11-14] and were shown to display similar phenotypes, these include hypersensitivity to DNA crosslinking agents, increased spontaneous and induced chromosomal breakage and germ cell loss leading to reduced fertility. Studies using the Fancc -/- mice have shown that lack of Fancc resulted in a reduced number of $\mathrm{CD} 34^{+}$stem cells [17]. Since the murine CD34 marker has been associated not only with the differentiation state or short-term repopulating cells, but also with activation and/or cycling state [24,35], the reduced number of CD34+ cells in Fancc/- mice and the fact that Fancc-/- stem/progenitor cells (Lin'c-Kit ${ }^{+} \mathrm{Sca}-1^{+}$) were shown to be less quiescent [36] may also reflect an altered activation state. Murine Brca1 and Brca2 mRNA expression was shown to be up-regulated in rapidly proliferating cells indicative of a role in proliferation and differentiation control [37]. Also, murine Fancg mRNA was shown to be expressed in highly proliferative and embryonic tissues [31]. Since Fancc-/progenitor/stem cells were shown to be less quiescent [36], our results showing increased Brca1 and Brca2/ Fancd1 mRNA expression levels in Fancc-/- BM cells would be consistent with an altered proliferation state. However, this is not the case with Fancg expression pattern, where mRNA levels were found to be dramatically reduced in Fancc -/- LTS-CD34+ cells. Thus, the increased expression levels of Brca1 and Brca2/Fancd1 in Fancc-/- cells and reduced Fancg expression in CD34+ cells may not be a consequence of an increase in proliferation but may reflect disregulated gene expression due to absence of Fancc. The role that Fancc might have on other FA gene expression has yet to be determined.

\section{Conclusions}

Together our results show that FA genes are regulated at the mRNA level that increased Fancc expression in LTS$\mathrm{CD} 34^{+}$cells correlates with a role at the CD34+ differentiation stage and that lack of Fancc downregulates Fancg expression in $\mathrm{CD}_{34}{ }^{+}$stem cells but increases Brcal and Brca2/Fancd1 expression in all BM cell populations. Differential expression of FA genes in hematopoietic cell population suggest that FA genes may have distinct function at different stem cell stages but that Fancc and Fancg may function specifically at the $\mathrm{CD} 34^{+}$differentiation stage.

\section{Competing interests}

None declared.

\section{Authors' contributions}

MA performed hematopoietic cell purifications, mRNA extractions, RT-PCR and analysis of FA genes. ML performed hematopoietic cell purifications, mRNA extraction, RT-PCR and analysis of Brca genes. IB performed Western blot and immunoprecipitation studies. MCD was responsible for maintaining the mouse colony and participated in hematopoietic cell purifications. MC conceived the study and participated in its design and coordination. All authors read and approved the final manuscript.

\section{Acknowledgments}

This work was supported by grants from the Canadian Institutes of Health Research (ClHR), the Fanconi anemia Research Fund inc., the Fanconi Canada foundation, a CIHR junior investigator award (M.C.) and training awards from "La Fondation de la recherche sur les maladies infantiles (M.A). We wish to thank Dr. Manuel Buchwald for providing the Fancc knockout mice and Drs. Hans Joenje and Henri van de Vrugt for providing murine Fancf primer sequences. We also wish to thank Dr. Maurice Dufour for technical assistance in flow cytometry and Dr. Georges Levesque for his helpful comments on the manuscript.

\section{References}

I. Liu JM: Fanconi's anemia Bone marrow failure syndromes Edited by: Neal S Young. Philadelphia, W.B. Saunders company; 2000:47-68.

2. Joenje $\mathrm{H}$ and Patel $\mathrm{KJ}$ : The emerging genetic and molecular basis of Fanconi anaemia Nat Rev Genet 200I, 2:446-457.

3. Strathdee CA, Gavish H, Shannon WR and Buchwald M: Cloning of cDNAs for Fanconi's anaemia by functional complementation Nature 1992, 358:434.

4. Lo Ten Foe JR, Rooimans MA, Bosnoyan-Collins L, Alon N, Wijker M, Parker L, Lightfoot J, Carreau M, Callen DF, Savoia A, Cheng NC, van Berkel CG, Strunk MH, Gille JJ, Pals G, Kruyt FA, Pronk JC, Arwert F, Buchwald $M$ and Joenje $H$ : Expression cloning of a cDNA for the major Fanconi anaemia gene, FAA Nat Genet 1996, I4:320-323.

5. de Winter JP, Waisfisz Q, Rooimans MA, van Berkel CG, BosnoyanCollins L, Alon N, Carreau M, Bender O, Demuth I, Schindler D, Pronk JC, Arwert F, Hoehn H, Digweed M, Buchwald M and Joenje H: The Fanconi anaemia group G gene FANCG is identical with XRCC9 Nat Genet 1998, 20:281-283.

6. de Winter JP, Rooimans MA, van Der Weel L, van Berkel CG, Alon N, Bosnoyan-Collins L, de Groot J, Zhi Y, Waisfisz Q, Pronk JC, Arwert F, Mathew CG, Scheper RJ, Hoatlin ME, Buchwald M and Joenje H: The Fanconi anaemia gene FANCF encodes a novel protein with homology to ROM Nat Genet 2000, 24:I5-I6.

7. de Winter JP, Leveille F, van Berkel CG, Rooimans MA, van Der Weel L, Steltenpool J, Demuth I, Morgan NV, Alon N, Bosnoyan-Collins L, Lightfoot J, Leegwater PA, Waisfisz Q, Komatsu K, Arwert F, Pronk JC, Mathew CG, Digweed M, Buchwald $M$ and Joenje $H$ : Isolation of a cDNA representing the Fanconi anemia complementation group E gene Am J Hum Genet 2000, 67:1306-I308.

8. Timmers C, Taniguchi T, Hejna J, Reifsteck C, Lucas L, Bruun D, Thayer M, Cox B, Olson S, D'Andrea AD, Moses R and Grompe M: Positional cloning of a novel Fanconi anemia gene, FANCD2 Mol Cell 200I, 7:24I-248.

9. The, Fanconi, anaemia/breast, cancer and consortium: Positional cloning of the Fanconi anaemia group A gene. Nat Genet 1996, I 4:324-328.

10. Howlett NG, Taniguchi T, Olson S, Cox B, Waisfisz Q, De DieSmulders C, Persky N, Grompe M, Joenje H, Pals G, Ikeda H, Fox EA and D'Andrea AD: Biallelic Inactivation of BRCA2 in Fanconi Anemia Science 2002, 297:606-609.

II. Chen M, Tomkins DJ, Auerbach W, McKerlie C, Youssoufian H, Liu L, Gan O, Carreau M, Auerbach A, Groves T, Guidos C), Freedman $\mathrm{MH}$, Cross J, Percy DH, Dick JE, Joyner AL and Buchwald M: Inactivation of Fac in mice produces inducible chromosomal instability and reduced fertility reminiscent of Fanconi anaemia Nat Genet 1996, I 2:448-45I. 
12. Whitney MA, Royle G, Low MJ, Kelly MA, Axthelm MK, Reifsteck C, Olson S, Braun RE, Heinrich MC, Rathbun RK, Bagby GC and Grompe $M$ : Germ cell defects and hematopoietic hypersensitivity to gamma- interferon in mice with a targeted disruption of the Fanconi anemia C gene Blood 1996, 88:49-58.

13. Cheng NC, van de Vrugt $H$, van der Valk MA, Oostra AB, Krimpenfort $\mathrm{P}$, de Vries $\mathrm{Y}$, Joenje $\mathrm{H}$, Berns $\mathrm{A}$ and Arwert F: Mice with a targeted disruption of the Fanconi anemia homolog Fanca Hum Mol Genet 2000, 9: |805-|8||

14. Yang Y, Kuang Y, De Oca RM, Hays T, Moreau L, Lu N, Seed B and D'Andrea AD: Targeted disruption of the murine Fanconi anemia gene, Fancg/Xrcc9 Blood 200I, 98:3435-3440.

15. Carreau M, Gan Ol, Liu L, Doedens M, McKerlie C, Dick JE and Buchwald $M$ : Bone marrow failure in the Fanconi anemia group C mouse model after DNA damage Blood 1998, 9 I :27372744.

16. Haneline LS, Gobbett TA, Ramani R, Carreau M, Buchwald M, Yoder $M C$ and Clapp DW: Loss of Fanc $C$ function results in decreased hematopoietic stem cell repopulating ability Blood I999, 94: I8.

17. Carreau M, Gan OI, Liu L, Doedens M, Dick JE and Buchwald M Hematopoietic compartment of Fanconi anemia group $C$ null mice contains fewer lineage-negative CD34+ primitive hematopoietic cells and shows reduced reconstitution ability Exp Hematol 1999, 27:1667-1674.

18. Lu SJ, Li F, Vida L and Honig GR: Comparative gene expression in hematopoietic progenitor cells derived from embryonic stem cells Exp Hematol 2002, 30:58-66.

19. Oh IH, Lau A and Eaves C): During ontogeny primitive (CD34(+)CD38(-)) hematopoietic cells show altered expression of a subset of genes associated with early cytokine and differentiation responses of their adult counterparts Blood 2000, 96:4160-4168

20. Brady G, Billia F, Knox J, Hoang T, Kirsch IR, Voura EB, Hawley RG Cumming $R$, Buchwald $M$ and Siminovitch $K$ : Analysis of gene expression in a complex differentiation hierarchy by global amplification of cDNA from single cells Curr Biol 1995, 5:909. 922.

21. Zinovyeva MV, Zijlmans JM, Fibbe WE, Visser JW and Belyavsky AV: Analysis of gene expression in subpopulations of murine hematopoietic stem and progenitor cells Exp Hematol 2000, 28:318-334

22. Sauvageau G, Lansdorp PM, Eaves C], Hogge DE, Dragowska WH, Reid DS, Largman C, Lawrence HJ and Humphries RK: Differentia expression of homeobox genes in functionally distinct CD34+ subpopulations of human bone marrow cells Proc Nat Acad Sci U S A 1994, 91: I2223-12227.

23. Zanjani ED, Almeida-Porada G, Livingston AG, Porada CD and Ogawa M: Engraftment and multilineage expression of human bone marrow CD34- cells in vivo Ann N Y Acad Sci 1999, 872:2203I; discussion 23I-2.

24. Osawa M, Hanada $\mathrm{K}$, Hamada $\mathrm{H}$ and Nakauchi H: Long-term lymphohematopoietic reconstitution by a single CD34-low/negative hematopoietic stem cell. Science 1996, 273:242-245.

25. Ito T, Tajima F and Ogawa M: Developmental changes of CD34 expression by murine hematopoietic stem cells Exp Hematol 2000, 28: $1269-1273$

26. Pang Q, Christianson TA, Keeble W, Diaz J, Faulkner GR, Reifsteck $C$, Olson S and Bagby GC: The Fanconi anemia complementation group $C$ gene product: structural evidence of multifunctionality Blood 200I, 98: |392-|40|

27. Futaki M, Igarashi T, Watanabe S, Kajigaya S, Tatsuguchi A, Wang J and Liu JM: The FANCG Fanconi anemia protein interacts with CYP2EI: possible role in protection against oxidative DNA damage Carcinogenesis 2002, 23:67-72.

28. Cumming RC, Lightfoot J, Beard K, Youssoufian H, O'Brien PJ and Buchwald $M$ : Fanconi anemia group $C$ protein prevents apoptosis in hematopoietic cells through redox regulation of GSTPI Nat Med 2001, 7:814-820.

29. Kruyt FA, Hoshino T, Liu JM, Joseph $P$, Jaiswal AK and Youssoufian $H$ Abnormal microsomal detoxification implicated in Fanconi anemia group $C$ by interaction of the FAC protein with NADPH cytochrome $\mathbf{P 4 5 0}$ reductase Blood 1998, 92:3050 3056
30. Abu-Issa R, Eichele $G$ and Youssoufian H: Expression of the Fanconi anemia group $A$ gene (Fanca) during mouse embryogenesis Blood 1999, 94:818-824.

31. Krasnoshtein F and Buchwald $M$ : Developmental expression of the Fac gene correlates with congenital defects in Fanconi anemia patients Hum Mol Genet 1996, 5:85-93.

32. Nadler J] and Braun RE: Fanconi anemia complementation group $\mathbf{C}$ is required for proliferation of murine primordial germ cells Genesis 2000, 27: I I7-I23.

33. Wevrick R, Clarke CA and Buchwald $M$ : Cloning and analysis of the murine Fanconi anemia group C cDNA Hum Mol Genet 1993, 2:655-662

34. Sato T, Laver JH and Ogawa M: Reversible expression of CD34 by murine hematopoietic stem cells Blood 1999, 94:2548-2554.

35. Haneline L, Li X, Plett A, Hong P, Yoder M, Orschell-Traycoff CM and Clapp DW: Hematopoietic stem cell quiescence is dependent on the Fanconi anemia complementation type $C$ gene product Blood 200I, 98:216a.

36. Rajan JV, Wang M, Marquis ST and Chodosh LA: Brca2 is coordinately regulated with Brcal during proliferation and differentiation in mammary epithelial cells Proc Natl Acad Sci U S A 1996, 93:13078-13083.

37. van de Vrugt HJ, Koomen M, Berns MA de Vries $Y$, Rooimans MA van der Weel L, Blom E, de Groot J, Schepers RJ, Stone S, Hoatlin ME, Cheng NC, Joenje $\mathrm{H}$ and Arwert F: Characterization, expression and complex formation of the murine Fanconi anaemia gene product Fancg Genes Cells 2002, 7:333-342.

\section{Pre-publication history}

The pre-publication history for this paper can be accessed here:

\section{http://www.biomedcentral.com/1471-2326/3/1/prepub}

Publish with Bio Med Central and every scientist can read your work free of charge

"BioMed Central will be the most significant development for disseminating the results of biomedical research in our lifetime. "

Sir Paul Nurse, Cancer Research UK

Your research papers will be:

- available free of charge to the entire biomedical community

- peer reviewed and published immediately upon acceptance

- cited in PubMed and archived on PubMed Central

- yours - you keep the copyright

Submit your manuscript here:

http://www.biomedcentral.com/info/publishing_adv.asp
BioMedcentral 